(2015) 3 NIBLeJ 7

\title{
Path Dependent Obstacles to Cross- Border Insolvency: a Social Darwinian Perspective
}

\author{
Jennifer L. L. GANT*
}

\section{Conflict of Laws and Insolvency Coordination: an Introduction ${ }^{123}$}

1 The coordination of legal systems has been a subject of discussion and innovation for legislators, political leaders, legal academics and businessmen for centuries, particularly with the aim of facilitating business across borders in order to maximise the economic benefits of international trade. The lex mercatoria has persisted since the Middle Ages as a form of private international law aimed at facilitating cross-border trade. It provides a body of rules and principles, distinct from the ordinary laws of a single jurisdiction, which developed from a need for simplified financial transactions that avoided risk of transporting hard currency over the long distances travelled by merchants to partake in regional faires and markets throughout Europe. These rules aimed to create a framework within which commercial transactions between travelling merchants could take place. While commercial rules in Europe have never been completely uniform, the lex mercatoria offered a means of coordinating the trading customs among different countries $^{4}$ without recourse to specific legal rules. International trade continues to

\footnotetext{
* Jennifer Gant is a Casual Lecturer at the Nottingham Law School and Research Assistant in the Centre for Business and Insolvency Law. She is currently writing up her PhD in insolvency, employment and comparative law under the supervision of Professors David Burdette and Paul Omar.

${ }^{1}$ A substantial part of the inspiration for this article is derived from the Edwin Coe Lecture given by Professor Ian Fletcher entitled: "Spreading the Gospel: The Mission of Insolvency Law and Insolvency Practitioners in the early $21^{\text {st }}$ century", delivered on 26 September 2013 at the INSOL Europe Academic Forum Conference held in Paris, France.

${ }^{2}$ Part of the content in this article was delivered in a presentation at the INSOL International Academic Colloquium Annual Conference in Hong Kong in March 2014 based on a paper entitled "Obstacles to Cross-border Insolvency and Employment Protection Coordination in the EU: Examples from the UK and France".

${ }^{3}$ The author would like to thank the anonymous referees for comments on the article. All remaining errors are the author's own.

${ }^{4}$ W. Mitchell, An Essay on the Early History of the Law Merchant (1904, Cambridge University Press, Cambridge), at 10 .
} 
be governed by customary rules derived from the lex mercatoria, transcending traditional state law and municipal legal forms and institutions. ${ }^{5}$ These norms are now supplemented by international legal rules set by organisations such as the World Bank, UNIDROIT, ${ }^{6}$ UNCITRAL $^{7}$ and the International Labour Organisation. Though such transnational norms tend to have no effective enforcement mechanism, they have helped to align legal systems to the extent that they have aided the development of a reasonably productive and effective European and, indeed, global marketplace. Where businesses exist, so too do business failures. Thus, a fundamentally essential element of international trade norms is the coordination of rules on the insolvency of companies engaging in cross-border trade.

2 While easing the mode of business transactions across-borders, norms of international trade have not necessarily facilitated the coordination of legal decision making and enforcement as these activities are inextricably tied into the legal culture of a jurisdiction and often carry with them a sense of judicial selfimportance. This is particularly relevant for insolvency cases as they will often have assets, subsidiaries, employees or other associations in multiple jurisdictions and may therefore need to interact with multiple courts. In order to accomplish a level of coordination that would avoid overly complex and costly cross-border procedures, it was necessary to create sets of norms that would facilitate the resolution of legal conflicts. The establishment of jurisdiction and the coordination of judicial decision-making for cross-border legal problems began with interstate agreements creating rules to deal with the conflict of laws, in order to guarantee the uniformity of decisions and legal certainty across the states party to this or that international agreement. ${ }^{8}$ There has been a steady development of arguments in favour of the uniformity of rules, universality of application and the coordination of laws at an international level which, for insolvency procedures, helps by avoiding a proliferation of procedures that would be costly for the company and reduce returns to creditors. ${ }^{9}$

3 Within the European Union, ${ }^{10}$ coordination and uniformity have been achieved to some extent in those legal areas that deal with the free movement of goods and capital in pursuit of free trade within the Common Market. The European

\footnotetext{
5 N. Hatzimihail, "The many Lives - and Faces - of Lex Mercatoria: History as Genealogy in International Business Law" (2008) 71 Law and Contemporary Problems 169-190, at 171.

${ }^{6}$ The Rome International Institute for the Unification of Private Law.

${ }^{7}$ United Nations Commission on International Trade Law.

8 P. Neuhaus, "Legal Certainty versus Equity in the Conflict of Laws" (1963) 28(4) Law and Contemporary Problems 795-807, at 798.

9 P. Omar, "Jurisdictional Criteria and Paradigms in International Insolvency Texts" (2012) 12(1) Insolvency Law Journal 7-27.

${ }^{10}$ Hereafter referred to as the "EU".
} 
Insolvency Regulation ${ }^{11}$ is one of many attempts to coordinate the way in which Member States work together in cross-border business relationships. While the EIR has set out rules through which cross-border insolvencies can be managed, there remain gaps between individual insolvency systems that make it more difficult to coordinate insolvency procedures than if they were more closely aligned. Despite hard and soft law attempts to engender coordination, the mutual trust required remains difficult to capture. There are a number of reasons for this, not least of which are the pre-existing differences in insolvency law and procedures among the Member States. Disparities between the nature and standards of organisation, training and regulation of professionals and courts add additional obstacles, all of which adversely affect the effective coordination of insolvency systems by creating an atmosphere of mistrust due to the divergent characteristics of Member State legal systems and a resulting perceived imbalance in Common Market competition of Member State legal systems. ${ }^{12}$ In addition, due to factors specific to each jurisdiction, differing fundamental aims of insolvency present an obstacle to crossborder cooperation. Disparities in the aims of regulation tend to be influenced by factors that go beyond legal rules and political position of the jurisdiction in question. They are influenced by factors endemic to the jurisdictions within which they are found, reliant upon the historical paths upon which legal developments have trod over time.

4 What is the explanation of the idiosyncratic disparities between insolvency systems and is there any way that they can be aligned in spite of them? Why is it that if all Member States wish to promote effective and profitable cross-border business transactions that aligning those systems under which such transactions operate is such a difficult problem to address and resolve? This may seem a naive question, but trite answers will not assist on the way to better coordination. As such, a deeper analysis of the sources of the obstacles to legal coordination may help to elucidate the reasons why such obstacles exist and in so doing, perhaps make it possible to promote a closer alignment that can account for systemic differences when drafting or reforming coordinating legislation rather than attempting to force them into a common perspective. The jurisdiction specific characteristics that form the foundation upon which socio-economic, cultural and historical obstacles are rooted were referred to implicitly in Professor Ian Fletcher's Edwin Coe lecture, given at the INSOL Europe Academic Forum Paris conference in 2013, out of which was borne the inspiration for this investigation. While acknowledging that obstacles exist that inhibit coordination of insolvency laws at

\footnotetext{
${ }^{11}$ Council Regulation (EC) No 1346/2000 of 29 May 2000 on insolvency proceedings, OJ L 160/1 (hereafter referred to as the "EIR").

12 I. Fletcher QC, "Spreading the Gospel: the Mission of Insolvency Law, and the Insolvency Practitioner, in the Early Twenty-First Century", Chapter 17 in The Grand Project: Reform of the European Insolvency Regulation: Papers from the INSOL Europe Academic Forum and Academy of European Law Joint Insolvency Conference Trier, Germany, 18-19 March 2013 and the INSOL Europe Academic Forum Annual Conference Paris, France 25-26 September 2013 (2014, INSOL Europe, Nottingham and Paris) 193-210, at 200.
} 
the EU level is a starting place to a broader perspective of the problem, a deeper understanding of the path dependent legal developments of the jurisdictions that are gathered under the coordinating rules of the EIR may assist in understanding the deep culturally related obstacles preventing a more reliable form of mutual trust and, in so doing, reveal potential new paths toward more effective universalism in the coordination of insolvency proceedings.

5 There are complex factors that exist within the legal, political, cultural, social and economic histories of each Member State that contribute to the diversity of aims of legal regulation. These unique historical experiences influence the developmental path of individual legal systems. While insolvency laws are influenced by a myriad of historical, social, economic and political characteristics, the focus of this treatise will be the path dependent influence of social policy and regulation on the legal development of insolvency law and the aims that individual jurisdictions ascribe to it. This will provide a snapshot of a far more complex framework that can explain how along just a single thread of historical development, a whole area of law can be fundamentally affected and differentiated from parallel developments in another legal system. There is a complexity of diverse legal development in the social policies and regulation of Member States, which has an effect on the aims of insolvency law in the relative weight of protection given to creditors and employees. By way of example, the United Kingdom ${ }^{13}$ and France will be used as comparators.

\section{Theoretical Framework: Path Dependency}

6 A comparison of a civil law and common law system cannot be made without some reference to differences arising from legal origins. While the basis of this treatise is examining a far wider perspective of influences on legal development, a country's legal origin has an important role to play in these developments as well. The structure of a legal system influences how social control is applied to economic life ${ }^{14}$ and can influence national regulatory styles, ${ }^{15}$ which will affect jurisdictional approaches to the development of legal rules. In general it has been observed that common law systems are more likely to produce efficient rules for the governance of business enterprises than civil law systems and are less interventionist in their regulatory style. However, there are other historical and cultural factors that have a fundamental influence on the regulatory styles, particular to each jurisdiction. ${ }^{16}$ The

\footnotetext{
${ }^{13}$ Hereafter referred to as the "UK".

${ }^{14}$ R. La Porta, F. Lopez-de-Silenes and A. Shleifer, "The Economic Consequences of Legal Origins" (2008) 42(2) Journal of Economic Literature 285-332, at 286.

${ }^{15}$ S. Deakin, P. Lele and M. Siems, "The Evolution of Labour Law: Calibrating and Comparing Regulatory Regimes" (2007) 46(3-4) International Labour Review 133-162, at 133.

16 B. Ahlering and S. Deakin, "Labour Regulation, Corporate Governance and Legal Origin: a Case of Institutional Complementarity?" (2007) 41(4) Law \& Society Review 895-908, at 867.
} 
theory of legal origins attempts to explain differences in regulatory style through an examination of the systemic differences between common law and civil law systems and has done so through a number of empirical observations. ${ }^{17}$

7 While true that the legal origins of a jurisdiction will form a fundamental basis upon which legal systems evolve, understanding the reasons why differences in legal systems persist in modern Western cultures in this globalised economic world view cannot be explained only by examining legal origins in isolation. Not every civil system underwent the same historical experiences and thus will have evolved with different trajectories that cannot be explained by narrow view of legal origins alone. It is therefore necessary to delve deeper into the socio-cultural, political economic and historical factors that have led to the current state of the law to fully understand why it is the way that it is. There are too many other variables that the legal origins theory has failed to account for, making the theory unviable for broad application without qualification.

8 According to Richard Posner, law is the most historically oriented, backward looking and path dependent of the professions, venerating tradition, precedent, custom, ancient practices and texts, wisdom and an interpretative method that is inextricably linked to its history. The characteristic gerontocracy of the profession relies upon ingrained attitudes that are obstacles to any attempt to reorient the law to a more pragmatic, and for the purpose of this treatise, coordinated and efficient direction. ${ }^{18}$ The fundamental dependence of the law on its history is evident in how precedent functions in common law systems and how codes drafted decades or more in the past continue to provide the foundation of civil law systems. ${ }^{19}$ While the historical dependence of law is self-evident, its context in the wider history of a jurisdiction also plays an important role in how law develops.

9 The object of this article is to explore the historical context of social policy in the UK and France and analyse how it has influenced their approaches to insolvency law and corporate rescue. This methodological approach is based on the concept of path dependence, a theory suggesting that established traditional legal approaches to resolving legal problems will determine how new situations are dealt with in the present and in the future. ${ }^{20}$ Decisions made by legislators or judges are shaped in specific and systemic ways by the historical path leading up to them. ${ }^{21}$ Thus legal developments can be explained by reference not only to the specific characteristics of the legal system, but also by superimposing the social and economic pressures

\footnotetext{
${ }^{17}$ Ibid., at 867 .

${ }^{18}$ R. A. Posner, "Past-Dependency, Pragmatism and Critique of History in Adjudication and Legal Scholarship" (2000) 67(3) The University of Chicago Law Review 573-606, at 873.

19 O. A. Hathaway, "Path Dependence in the Law: The Course and Pattern of Legal Change in a Common Law System" (2000) 86 Iowa Law Review 601-665, at 601.

${ }^{20}$ J. Bell, "Path Dependence and Legal Development" (2012) 87 Tulane Law Review 787-810, at 787788.

${ }^{21}$ Hathaway, above note 19 , at 604
} 
operating on the law from the outside as well as the established, perhaps culturally motivated, ways of dealing with legal issues within the system. While economic and social conditions may be similar in different countries, the differences in the paths on which legal systems have journeyed are not. An understanding of extralegal factors connected to a country's history will assist in explaining why they do not approach similar, new problems in the same way. ${ }^{22}$ This theory adds to the legal origins hypothesis, which is too narrow to adequately explain all legal differences.

10 Path dependency thus demonstrates how history influences the process of legal change and implies that the events of an earlier point in time affect the possible outcomes of a sequence of events occurring at a later point in time. ${ }^{23}$ There is a certain Darwinian effect here, as essentially the success of an outcome in the past will lead to similar choices in the future, theoretically common to differential reproductive success in evolutionary theory ${ }^{24}$ This is particularly illustrative of UK legal development, though it does share some elements with the French, which reflects more of a "punctuated equilibria" of legal development. This second strand of evolutionary path dependence is reminiscent of the long periods of French status quo punctuated by periods of explosive revolution, similar in biology to periods of rapid adaptation in which changes occur only in fits and starts. Both the UK and France exhibit elements of both of these strands of evolutionary path dependency, but historically the French have experienced far more explosive change in their society and legal developments (consider that France has changed its Constitution no less than a dozen times since 1791). However, it is submitted that on the whole, "legal evolution" exhibits a combination of the two, but fundamentally, it is directly constrained by history. The legal possibilities for today and for the future are determined by the evolutionary changes of the past, whether slow and steady or explosive and revolutionary. Given the close, if frequently adversarial, relationship that the UK and France have historically shared, and the fact that both have exercised considerable influence in the EU through which insolvency coordination is meant to flow, they present two archetypal examples of how a state's historical roots influence its approach to legal problems, such as resolving business failure in an economically efficient manner, and the potential obstacles to legal reform that aims to achieve closer coordination in this area.

11 Before delving into the specific paths that this treatise intends to explore with a view to explaining the differences in current social policy regulation as it intersects with the procedures of corporate rescue and insolvency, a brief overview of the context of social policy in insolvency is required. This permits paths to be drawn from the historical descriptions that follow to the parallel analysis in the concluding remarks that will illuminate the evolutionary intersections in today's British and

\footnotetext{
${ }^{22}$ Bell, above note 20 , at 787-788.

${ }^{23}$ W. Sewell, "Three Temporalities: Toward an Eventful Sociology", in W. Sewell, Logics of History: Social Theory and Social Transformation (2005, University of Chicago Press, Chicago) 81-124.

${ }^{24}$ See C. Darwin, On the Origin of Species (1859) (2008, Oxford University Press, Oxford).
} 
French insolvency systems.

\section{Social Policy, Insolvency and Corporate Rescue}

\section{Regulatory Competence of Social Policy in the EU}

12 Social policy has had an influence on the aims of regulation throughout the EU, particularly since the end of the Second World War. The individual character of social policy is evident in the hands-off approach taken by EU social legislation, which has had consequences for the implementation of any legislation having a social consideration. Insolvency laws are one of those areas where social considerations arise as the outcomes of insolvency procedures will impact individuals, small businesses and communities within which struggling businesses are located.

13 The EIR, ${ }^{25}$ while attempting to coordinate procedures for cross-border insolvency, leaves the procedures of each jurisdiction intact, relying upon mutual trust among judges, legal professionals, businesses and citizens to achieve its ends. The principle of mutual trust in insolvency coordination requires minimum standards and an understanding of the different legal traditions and methods among the Member States. ${ }^{26}$ The level of protection afforded to employees, creditors, shareholders and other stakeholders continues to vary, creating the environment of mistrust owing to perceived unfairness between insolvency systems and the imbalance in competition it creates. It has been accepted that for the time being a European insolvency regulation imposing procedural norms across all Member States is not possible owing to the individual character of state insolvency regimes and the aims that influence them to which Member States remain attached. The disparity between insolvency systems therefore continues to be an obstacle to effective coordination.

14 The individual character of regulatory regimes protected by EU legislative methods also means that the differences in protective labour legislation remain diverse. If one examines this in the context of cross-border insolvency, the fact that the EIR leaves the determination of employment rights and obligations to the law of the Member State applicable to the employment relationship, an important factor of insolvency is left uncoordinated. ${ }^{27}$ Employees enjoy a super-priority in some jurisdictions, such as France, which means that employee claims are accorded a

\footnotetext{
${ }^{25}$ The text was recently the subject of an update published in 2015, due to come into force in 2017.

${ }^{26}$ European Commission, COM (2010) 171 Final, 20.4.2010, Section 4, "Strengthening confidence in the European judicial area", available at:

<http://eur-lex.europa.eu/LexUriServ/LexUriServ.do?uri=COM:2010:0171:FIN:EN:PDF> (last viewed 6 February 2014).

${ }^{27}$ R. van Galen et al., Revision of the European Insolvency Regulation: Proposals by INSOL Europe (2012, INSOL Europe, Nottingham), at 23.
} 
greater preference over even the secured creditors as they benefit from a general lien over an employer's property in respect of unpaid wages. In the UK, employees also enjoy a preference, but this is severely restricted in relation to the amount that they can recover from the national guarantee fund ${ }^{28}$ when their employer is insolvent, after which any leftover claims rank in common with unsecured claims. However, a number of other countries fall between these extremes, but deal with employee claims in very different ways, which may result in claims being covered by part employer funded guarantee fund that secures all employee claims in some jurisdictions.

15 European Directives also receive differential treatment on implementation. For example the application of acquired rights legislation in each Member State, though governed by the Acquired Rights Directive 2001, ${ }^{29}$ remains diverse in relation to how employees are treated in insolvency. In addition, redundancy and dismissal laws will affect the financial success of corporate rescue procedures depending upon the level of protection given to employees in these situations. Acquired rights and collective redundancy provisions also provide for protective awards in the event that procedural consultation and information obligations are not met, which can add another sometimes significant level of costs that may hinder rescue procedures and reduce distributions to creditors in liquidation procedures.

16 While true that the EU Treaties have so far left the competence to regulate social policy to the Member States, ${ }^{30}$ since the Lisbon strategy of 2000 there has been a push to modernise the European social model by investing in human resources and combating social exclusion. However, these exhortations were lost in the financial crisis and Member State adherence to their sovereignty over social policy has thus far triumphed. ${ }^{31}$ In addition, the framework of the Europe 2020 strategy envisages further flexibilisation of the labour market that is to be achieved through interstate coordination and soft law initiatives. The methods have generally been shown to be less than effective in achieving truly closer coordination in social policy. Member States are looking to their own internal social problems in the still rippling wake of the financial crisis, particularly those countries that were forced to resort to loans from the famed troika of the International Monetary Fund, European Central Bank and the European Commission. The financial crisis has brought individual countries back into their protective shields of history and culture, making the path dependent nature of law and society all the more apparent. Thus, diverse

\footnotetext{
${ }^{28}$ Provided for by Directive 2008/94/EC of the European Parliament and of the Council of 22 October 2008 on the protection of employees in the event of the insolvency of their employee.

${ }^{29}$ Council Directive 2001/23/EC of 12 March 2001 on the approximation of the laws of the Member States relating to the safeguarding of employees' rights in the event of transfers of undertakings, businesses or parts of undertakings or businesses, Official Journal L 082/16 (22 March 2001).

${ }^{30}$ K-J. Bieback, "Harmonisation of Social Policy in the European Community" (1991) 32(4) Les Cahiers de Droit 913-935, at 916.

${ }^{31}$ G. Ross, "The Revenge of Neglected Issues: EU Founders and Social Policy" (2011) 29(2) French Politics, Culture and Society 90-104, at 95-100.
} 
social policy regulation among the Member States remains an obstacle to regulatory coordination in the EU.

\section{Evolutionary Ties of Social Policy and Corporate Rescue}

17 The persistence of social policy also influenced the very development of corporate rescue mechanisms that aim to preserve or rehabilitate a business and provided an additional feature underlying the overall rescue culture espoused throughout the EU. Prior to embracing the rescue culture in the UK, the aims of insolvency were quite simple: to replace the chaos occasioned by the pursuit of individual claims with a statutory regime suspending contractual rights and remedies while a mechanism provides for the orderly collection and realisation of assets and their distribution among creditors in accordance with a statutory scheme of distribution. ${ }^{32}$ The primary objectives of corporate insolvency law in England are geared toward maximising the return to creditors, whether this is through returning a company to profitable trading or dealing with the company's assets in such a way that creditors are able to regain the best possible return on their financial claims. ${ }^{33}$ By the 1980s, a more social approach to insolvency had developed among Western nations which left scope for, and indeed justified, rescue activities according to the individual values contained within the corporate rescue principles of each jurisdiction. ${ }^{34}$ Indeed, if aims remained the maximisation of returns for creditors, there would be no need for corporate rescue. By definition, it considers factors outside of the realm of the goals of the corporation.

18 The aims of insolvency in the UK were tempered by some element of social consideration first by the introduction of administration in the Insolvency Act $1986^{35}$ and then in 2002 with the introduction of more socially oriented procedures that aimed to rescue a business as a priority. ${ }^{36}$ One of Cork's ${ }^{37}$ primary concerns in introducing the administration procedure was the plight of the unsecured creditor, who generally received nothing in traditional insolvency procedures. The underlying feature of corporate rescue procedures is that they would also have a role in protecting jobs due to the continuance of the company and the various directives protecting employees affected by the business in either financial distress or in processes of restructuring. Cork's broad policy was aimed at the rehabilitation of the company and while the 1986 Act did not go as far as he perceived was necessary to achieve this end, the 2002 Act succeeded in implementing more

\footnotetext{
${ }^{32}$ R. Goode, Principles of Corporate Insolvency Law (2005, Sweet and Maxwell, London), at 5.

${ }^{33}$ Ibid., at 39.

${ }^{34}$ V. Finch, Corporate Insolvency Law: Perspectives and Principles (2009, Cambridge University Press, Cambridge), at 245-246.

351986 c. 45.

${ }^{36}$ Enterprise Act 2002 (2002 c. 40).

${ }^{37}$ K. Cork, Sir (Chairman), Insolvency Law and Practice: Report of the Review Committee (1982) Cmnd. 8558
} 
effective rehabilitative procedures. ${ }^{38}$

19 The 2002 Act also provided a greater degree of preference for employees in the distributions of insolvency, indicating another social matter imposed upon the economic purity of insolvency procedures. Though traditionally insolvency law has had other interests to look to, matters of fairness have now been accepted as necessary considerations in the UK insolvency system. Among these considerations are the ranking of wages as preferential debts, access to social security for repayment of arrears, rules dealing with continuity of employment and laws stipulating the mandatory transfer of contracts on the transfer of a business as a going concern. ${ }^{39}$ The latter of these protections is derived from EU law, but has been in existence elsewhere in continental Europe for decades. In particular, social policy issues such as the application of acquired rights are fundamental factors influencing the regulatory style in France.

20 In France, the aims of insolvency have encompassed social policy matters from prior to the time when the EU began to push toward rescue. The emphasis on social policy encouraged a move to the maintenance of businesses over liquidation. The harmful effects of unemployment caused by business failures in recessionary times were an influence on the creation of a corporate rescue policy heavily biased toward the protection of employment and the rehabilitation of the business. ${ }^{40}$ The French system exhibits redistribution tendencies that are characteristic of its version of social democracy. The French perspective of insolvency is as a collective procedure designed to distribute loss among all stakeholders in a company, subject to a certain hierarchy of distribution where employees are often privileged over creditors. $^{41}$ Its reform in the 1980 s had the essential objective of protecting employment at the risk of sacrificing creditors' rights. Creditors' rights were made secondary to the preservation of the business in difficulty and the jobs dependent upon it. ${ }^{42}$ This approach was later viewed as too biased in favour of labour and unsuited to allowing the French economy to evolve in the highly competitive global market. $^{43}$

21 While more recent reforms have softened the draconian treatment of creditors relative to employees, the objective of protecting employment continues to affect the way in which courts deal with specific insolvency cases. There is an underlying goal of preserving employment in the French system. Compromises are sometimes made between the social and financial objectives in the sale of businesses as going

\footnotetext{
${ }^{38}$ V. Finch, above note 34 , at 754-779.

${ }^{39}$ Ibid., at 15 .

40 A. Sorensen and P. Omar, Corporate Rescue Procedures in France (1996, Kluwer Law International, London), at 26.

${ }^{41}$ P. Omar, European Insolvency Law (2004, Ashgate Publishing Limited, Aldershot), at 129.

${ }^{42}$ J. Silkenat and C. Schmerler, The Law of International Insolvencies and Debt Restructurings (2006, Oceana Publications, New York), at 143.

43 Idem.
} 
concerns. ${ }^{44}$ The social objectives of employment protection and the attendant costs effectively reduce the value of a business being sold; thereby reducing the distributions available to creditors, though this is often acceptable due to the French emphasis on workers' rights and job security.

22 The fundamental aims of insolvency in the UK and France differ, primarily in respect of the applicable social objectives. Though similar terms to describe elements of procedure may be used, the ideologies and policies informing the objectives of those procedures result in an asynchronous meaning, creating a barrier to mutual understanding and an obstacle to coordinated action. The question remains then as to how it may be possible to find a means of coordinating the law in order to pursue a more successful environment for cross-border business. In discovering the influences on the aims of socially oriented regulation it may be possible to identify areas where coordination and perhaps convergence may be realistically attempted and to work around those areas in which the different social aims make such convergence impossible or at least improbable in the near future.

23 In order to identify the influences on the aims of socially oriented regulation as it affects insolvency and corporate rescue, certain specifically selected paths of regulatory development will be discussed in the following sections. The historical economic context is fundamentally important as social policies are inextricably linked to the economic systems within which they are found. Therefore, there will first be a description of the economic history of both jurisdictions before moving on to historical path development of industrialisation; proletarianisation of the working classes; idiosyncrasies of the employment relationship; collectivism and labour movements; and the evolution of labour regulation. Each of these historical developments have an impact on the evolution of social policy, which has a significant impact on the balance struck between the individual and the business, or in terms of this endeavour, the balance between the aims of social policy and the aims of corporate rescue and insolvency.

\section{Paths of Regulatory Development in Labour}

\section{Labour is not a Commodity}

24 It has long been recognised that differences in labour regulation between sovereign states is an obstacle to competition. Jacques Necker, financial minister to Louis XIV, argued that abolishing Sunday working would interfere with France's ability to compete in the international market. Robert Owen, grandfather of British labour law, in 1818 petitioned the powers that were at that time for a continent wide

\footnotetext{
${ }^{44}$ R. Stevens, "Comments and Discussion Report", in W-G. Ringe, L. Gullifer and P. Thery (eds), Current Issues in European Financial and insolvency Law: Perspectives from France and the UK (2009, Hart Publishing, Portland), at 207-210.
} 
regulation of working hours in order to achieve fair competition, while achieving some social justice for workers. Further, the constitution of the International Labour Organisation states that the failure of any nation to adopt humane conditions of labour is an obstacle in the way of other nations who desire to improve the conditions in their own countries. ${ }^{45}$ While it can be generally conceded that among Western European countries working conditions are generally humane, there remain discrepancies in how far each country goes on to ensure worker safety, autonomy and job security.

25 Labour law evolved in part to deal with the fact that the services provided by individuals cannot be separated from the person providing it. Though treated as a commoditized factor of production in explanations of a free market economy by classical economists, labour does not exhibit the normal qualities of a commodity. It is not purely subject to the law of supply and demand as, at least in modern times, workers often bargain in such a way that the balance between supply and demand in the labour market are compromised in order to improve their working lives. The only way labour could be and remain a commodity would be to regulate its ability to act on its own behalf, which for a long period of time is exactly what governments did to ensure uninhibited competition in the labour market to protect capitalism. The employee is also naturally subordinated by an employer in terms of relative power due to the organisational methods, capital ownership, priority of interests, as well as the economic dependency of the employee. The asymmetry of this relationship means that employers are able to essentially dictate employment terms that an employee will be forced to accept as the alternative may be unemployment. $^{46}$ This imbalance in the bargaining position of the contractual parties to the employment relationship is addressed by modern labour regulation in both jurisdictions.

26 During the 1980s, the substantial protections for labour interests and collective laissez faire in the UK underwent a rapid decline due to the intensity of labour regulation. Reasons for this massive weakening of labour interests in the UK were of a political nature as a Conservative government had been elected on a policy of labour flexibilisation. During this period, union power and activities were having a significant effect on the UK's ability to compete in the Common Market. The scope of collective laissez faire had come to provide significant power to industrial workers that often far outweighed the power of employers. The neo-liberal Conservative government recognised this as a problem for the UK's place in the world economy and began to chip away at the strength of union power until it was all but replaced by minimally protective labour regulation that provided just enough succour to keep most workers from revolution. While the opt in of the UK to the

\footnotetext{
45 B. Hepple, "New Approaches to International Labour Regulation" (1997) 26(4) Industrial Law Journal 353-366, at 356.

46 A. Goldin, "Global Conceptualisations and Local Constructions", in G. Davidov and B. Languille (eds), The Idea of Labour Law (2011, Oxford University Press, Oxford) 69-87.
} 
EU Social Charter by the Labour government in 1997 and its subsequent enactment of the raft of European labour law further mitigated the losses of labour in the 1980 s, the power of the unions would never recover.

27 France underwent contrasting developments when in the 1980s the Auroux laws instituting labour law reforms were enacted under the socialist government. And while more conservative elements of the French government have mitigated the extent of protection afforded at that time, levels of employment protection has remained high. ${ }^{47}$ The nineties and noughties have seen developments on an EU level that have affected both the UK and France, though most of these developments were already present in France to some degree. Following the financial and sovereign debt crisis, there was a general recoil from EU legal supremacy as Member States looked to their own critical internal problems. While it has been officially recognised that a general flexibilisation of the labour market would provide a reasonable means of achieving economic recovery, every EU Member State has approached this in different ways according to their particular perspective on social, economic and employment rights. Thus rather than coming closer in the last several years, labour regulation among the Member States has actually diverged in many ways, though some have been forced into regulatory submission due to the loans provided by EU and international funding institutions. The fact that draconian de-regulation, austerity requirements and a catastrophic sovereign debt crisis have been necessary to draw some jurisdictions into closer regulatory alignment demonstrates how under similar circumstances, countries at similar developmental stages can react quite differently. However, some may also agree that the variance in apparent developmental levels within the EU has not been helpful in this economic climate.

28 One may ask why it is that across Europe social policy issues remain such a sensitive subject when viewed in parallel with EU Treaty goals of harmonisation as well as the effects of the financial crisis. While there are a number of reasons why this may be the case, it is submitted that social policy in some states, such as the UK, is exogenous to the legal system while social policy in others, such as France, is endogenous. As such any legislation which will impact on society in some way will have social considerations in France that might not be recognised as requiring consideration within UK law unless imposed upon it from outside the norms of the legal system as evidenced by the frequent resistance the UK has had to EU social policy legislation while France has often provided a catalyst for its creation. The degree to which social policy issues influence the regulatory style of a jurisdiction can be explained to some extent by an examination of those historical factors that led up to the varied regulation concerning economic and social matters particularly in the context of industrialisation. In order to appropriately contextualise the social aspects of this investigation, some economic context is first required.

\footnotetext{
${ }^{47}$ Deakin, Lele and Siems, above note 15 , at 145-146.
} 
Economic Systems and Policy

29 The economic history of a country often begins with the firs recognition of land ownership by individuals and its commoditisation. During the Middle Ages, England was the more economically progressive of the two jurisdictions, though the term "progressive" should not be viewed as a subjectively positive descriptor. English progressiveness was accompanied by varying degrees of violence, deprivation and social discord. The treatment of landholding in England differed from that of France since the time of the Norman Conquest ${ }^{48}$ when the policy of "nulle terre sans seigneur" 49 was imposed, resulting in the reversion of all English lands into royal property and distributed in such a way as to strengthen the royal Norman government. ${ }^{50}$ Feudal France was largely decentralised by the sixteenth century with landholding residing in the feudal lords of the provinces, each holding absolute power over their particular jurisdiction. While the power of the French crown was officially centralised in the sixteenth century, in reality the land remained under the ownership of large landholders or became the property of the bourgeoisie through purchase. The mutual obligations of feudalism had broken down, however, and the nobles no longer held a power that rivalled the king. ${ }^{51}$

30 During the time of Henry VIII, ${ }^{52}$ land ownership acquired new motive and meaning. The dissolution of the monasteries freed vast tracts of land and property which could be sold by the crown to the highest bidder. The sale of property for commercial gain was the catalyst for the commoditisation of land. Landowners now viewed their estates as potential commercial assets to be exploited for profit, rather than a means to support whole communities on a traditional communal level. ${ }^{53}$ The enclosure $^{54}$ of common lands became a profitable expedient for commercially minded landowners. The English pseudo-feudal system was being replaced by the laws of the market. Custom was replaced by law and contract while communal production was being supplanted by competition. The corporatized farmers benefitting from enclosure wished to sell their produce to the rising populations of

\footnotetext{
48 11th century invasion and occupation of England by an army of Norman, Breton and Frank soldiers led by William the Conqueror (Duke William II of Normandy) culminating in the Battle of Hastings on 14 October 1066 when the King of England, Harold Godwinson, brother-in-law to King Edward the Confessor, was defeated and killed by William's forces.

49 Translates as "no land without a lord" or "no property without a liege" and refers to the feudal law principle that a person provides services to his sovereign, usually by serving in the army, in return for the right to receive land from the sovereign.

${ }^{50}$ R. Allen Brown, Origins of English Feudalism (1973, George Allen and Unwin Ltd, London), at 3382.

${ }^{51}$ C. Jenkins, A Brief History of France: People, History and Culture (2011, Constable and Robinson Limited, London), at 26-45.

52 Reigned from 1509-1547.

${ }^{53}$ C. Hibbert, The English: A Social History 1066-1945 (1987, Guild Publishing, Glasgow), at 177.

${ }^{54}$ Enclosure refers to the process in England of fencing land that had previously been used under traditional rights of common land for grazing and arable farming and deeding that land to one or more owners who would then be solely entitled to use the land.
} 
towns and cities while smaller farmers were reduced to subsistence farming in small tenancies reliant on the landowner's willingness to continue the lease. Land was no longer managed in a way that required the mutuality of communal social responsibility. ${ }^{55}$ The English people were beginning to view profit as an appropriate ambition and began to work towards more capitalistic goals.

31 Land was commoditized as theological attitudes toward money and industry changed, first in England in the sixteenth century and later in France precipitated by the ideals of the French Revolution. ${ }^{56}$ This was made possible in part through the separation of the political from the spiritual after the power of the Church was usurped in both countries, Church lands confiscated and used for profit and rationalism overtook the predominate outlook of great leaders. The economy was no longer structured on custom and tradition but on the quest for economic profit. ${ }^{57}$ Despite the deprivations suffered by many, the expansion of a money based economy encouraged social mobility. The commercial classes were strengthened and an embryonic form of capitalism was growing, ${ }^{58}$ along with an interest in commercial and industrial innovation aimed at expanding and increasing the efficiency and profit trade. Though both countries steadily became more secular in nature, if not in form, they did so from different religious contexts. France remained Catholic while the UK had espoused a Tudor Protestantism. These differences also had an effect on legal evolution, particularly in relation to views on debt and social protection.

32 Capitalist motivations did not become common in France until the late nineteenth century. In fact, even following the French Revolution, going into business carried a social stigma even for the bourgeoisie, whose aim in making money was not for the sake of profit or investment, but generally in order to have enough to live an idle life and perhaps to purchase official positions. These goals are very much ancien régime principles that, though defeated in the aristocracy during the violence of the Revolution, were revived by the rising bourgeoisie who failed to grasp the benefits of true capitalism. They generally preferred to withdraw from business once personal goals were achieved, rather than beginning the large dynastic enterprises common in England and the United States.

33 Mercantilism also remained the dominant economic policy in France for some time. Mercantilism was an economic system that preceded capitalism and referred to the conviction that in order to prosper, states should manipulate every available advantage to create the best environment for prosperity. This was essentially the

\footnotetext{
${ }^{55}$ P. Ackroyd, The History of England Volume II: Tudors (2012, Pan Books, London), at 22-24 and 207.

${ }^{56}$ Period of political and social upheaval that lasted from 1789 to 1799 resulting in the abolition of the French monarchy and the establishment of a secular and democratic republic.

57 D. Goldman, Globalisation and the Western Legal Tradition: Recurring Patterns of Law and Authority (2007, Cambridge University Press, Cambridge), at 163 and 165-166.

${ }^{58}$ N. Davies, Europe: A History (1997, Pimlico, London), at 517.
} 
opposite of the laissez-faire principles adopted by eighteenth century classical economists, several of whom were French in origin. The mercantilist system discouraged imports through financial restrictions while encouraging exports and promoting manufacturing at home. It concerned itself with strengthening the sources of economic power while suppressing competition with economic rivals. ${ }^{59}$ Mercantilism was not able to support the economic growth for which it had been instituted, however. In the early eighteenth century, a conviction grew that economic life could not progress further unless states discontinued the application of artificial curbs and restrictions on trade. In France in particular, revolutionary notions of social welfare were being voiced by notable physiocrats, ${ }^{60}$ who theorised that national economic prosperity could not be assured but through the personal prosperity and liberty of all. ${ }^{61}$

34 Late seventeenth century Britain was receptive to changes to social and trading systems as it had achieved a fairly stable compromise following the Glorious Revolution of $1688 .^{62}$ Rather than a violent revolution led by disenfranchised and mistreated peasants and the middle class, this English revolution was bloodless and politically motivated, though with ostensibly religious aims: to prevent absolutist and radical Catholicism from usurping the Protestant establishment. However, political power continued to reside in the hands of the gentry and while the economy changed from being agriculturally and based managed by rich landowners to an industrial society dominated by industrial and financial capitalists, its success was all achieved within a constitutional framework of parliamentary supremacy. The power of the rich were further evidenced in the labour laws passed in 1799 and 1800 that repressed trade unions and striking in order to protect the interests of employers. ${ }^{63}$

35 France experimented with early forms of capitalist endeavour at various times prior to the French Revolution. However, there was little interest in taking innovative or risky investment opportunities and the attitudes of the bourgeoisie who were able to afford it were risk averse and more interested in purchasing office positions under the ancien régime tradition. Despite the pre-Revolution progressive

\footnotetext{
${ }^{59}$ Ibid., at 523.

${ }^{60}$ French enlightenment economists who believed that the wealth of nations derived solely from the value of land agriculture or development and that such products should be highly priced. See F. Quesnay, J. de Gournay, and J.P. Dupont de Nemours and J. Turgot. Physiocracy is an opposing theory to Mercantilism and preceded the first modern economic school of classical economics.

${ }^{61}$ Davies, above note 58, at 602 .

62 The Revolution of 1688 during which King James II was overthrown by a union of English Parliamentarians with Dutch Stadtholder William III of Orange who successfully invaded an unresisting England and ascended the throne, ensuring Protestant succession by displacing the Catholic heir apparent with William's Protestant English wife, the daughter of King James.

${ }^{63}$ B. Hepple and P. O'Higgins, The Making of Labour Law in Europe: A Comparative Study of Nine Countries up to 1945 (1986, Hart Publishing, Portland), at 16-17.
} 
ideas of Colbert, ${ }^{64}$ his innovative plans ended in bankruptcy despite his heroic attempts to avoid it. ${ }^{65}$ The actions of John Law ${ }^{66}$ evoked further hostility toward the idea of capitalist enterprise after his actions and those of his investors caused a market crash that led to a return to the old ways of security seeking and risk avoidance. ${ }^{67}$ These outcomes also led to a general hostility toward paper money that continued until the nineteenth century when France finally established a modern banking system. ${ }^{68}$ The attitudes of the bourgeoisie of this period are reflective of common risk-averse and anti-capitalist attitudes which remain present in France today and are reflective of the slow and often resistant progress of industrialisation.

\section{The Industrial Revolution: Opposing Viewpoints}

36 The countries of the EU all underwent capitalist industrialisation at different times and under different political conditions during the eighteenth and nineteenth centuries. While there are many differences in the historical characteristics of the UK and France, some of the most significant and relevant differences emerged at the time of industrialisation. ${ }^{69}$ The Industrial Revolution led to the institution of formally free labour as workers were separated from the land and labour became a factor of production. Liberal economics insisted on the free exchange of all factors of production, including labour, which can be seen as a commoditisation of the human being. This was eventually tempered to a certain degree by the introduction of the welfare state, which provided a basis for organizing and spreading the risks inherent in the shift from agrarian to industrial society, particularly since wage labour had become the means of subsistence for a large majority of the population. ${ }^{70}$

37 There are a number of characteristics peculiar to the British people, economy and even geography that contributed to its ability to grow its industry on a grander scale than its continental neighbours. The genius of practical craftsmen coupled with underemployed capital, cheap labour and new techniques of mass production

\footnotetext{
${ }^{64}$ 1619-1683; French politician who served as the Minister of Finances under King Louis XIV who improved the state of French manufacturing and tried to save the French economy, though the king's war expenditure made this impossible.

${ }^{65}$ C. Seignobos translated from French by C. A. Phillips, A History of the French People (1933, Jonathan Cape Limited, London), at 249.

${ }^{66}$ A Scottish economists who was the Controller General of Finances of France under the Duke of Orleans (regent for Louis XV) responsible for the Mississippi Bubble by exaggerating the wealth of Louisiana, leading to wild speculation on shares that ended in chaotic economic collapse in France.

${ }^{67}$ Jenkins, above note 51 , at 87.

${ }^{68}$ Idem.

${ }^{69}$ Hepple and O'Higgins, above note 63, at 5-6.

${ }^{70}$ S. Deakin and F. Wilkinson, The Law of the Labour Market: Industrialization, Employment and Legal Evolution (2005, Oxford University Press, Oxford), at 18-19.
} 
and a Protestant work ethic helped to push Britain to world economic leadership. ${ }^{71}$ There were a range of new inventions and thousands of patents taken out in the late eighteenth century. ${ }^{72}$ The capital available from the building of the colonial empire, developments in agriculture and the cottage industry provided Britain with a large domestic and colonial consumer market. Its economy was also isolated from continental Europe during the Napoleonic wars, which further stimulated British industry. ${ }^{73}$

38 As early as 1700, the English regions had already been effectively parcelled out into industrial provinces as certain areas specialised in certain industries, owing to specific conditions of the area. This led to a growth of industrial towns according to their nature and was aided by improved methods of transportation for foodstuffs necessary for an increased population. ${ }^{74}$ While industry had been evolving in England since the fifteenth century, it was during the middle of the eighteenth century that marks the beginning of an industrial as well as a commercial revolution in Britain that occurred in advance of any other European economy. ${ }^{75}$ In 1760 two thirds of British people were still living in the country and agriculture was still the largest occupations; however, Britain was growing phenomenally at this stage. ${ }^{76}$ Trade in the colonies had created the largest free trade area in the world while a new consumerism saw the rapid increase in demand for consumer goods. ${ }^{77}$ Thus, there was a need for large scale production, which industrialisation would seek to satisfy. Large populations of the countryside began to migrate into the cities to earn their living as factory workers. ${ }^{78}$

39 The gathering of labourers into a single place of work also characterised the Industrial Revolution as well as the changes it entailed to the labour processes and locations. In those industries that utilised processes of rolling and smelting it was nearly impossible to produce on a small scale. The mechanical limitations of the riverside water wheel utilised in mills and for engines also required more people to gather in the location where the technology was available for use. Oversight in terms of fraudulent and negligent practices also required a less disparate workforce. Finally, the division of labour and specialisation required the presence of a number of labourers doing specific jobs which fit into a whole process, requiring each element of that job to be located in the same place. ${ }^{79}$ The Industrial Revolution was

\footnotetext{
${ }^{71}$ J. Kelly, A Short History of Western Legal Theory (1992, Oxford University Press, Oxford), at 245 246.

${ }^{72}$ Hibbert, above note 53, at 468

${ }^{73}$ R. Lesaffer, European Legal History (2009, Cambridge University Press, Cambridge), at 376.

${ }^{74} \mathrm{~T}$. Ashton, An Economic History of England the $18^{\text {th }}$ Century (1955) (1972, Methuen \& Co Ltd, London), at 94-95.

${ }^{75}$ T. Ashton, The Industrial Revolution 1760-1830 (1947) (1977, Oxford University Press, Oxford), at 1.

${ }^{76}$ Kelly, above note 71 , at $245-246$

${ }^{77}$ Hibbert, above note 53, 466-467.

${ }^{78}$ Ashton, above note 75 .

${ }^{79}$ Ibid., at 88 .
} 
partly cause and partly an effect of the division of labour and the extension of specialisation. These new production methods allowed unskilled workers to devote themselves to a single product or process on a repetitive basis as a single element of an overall industrial endeavour. ${ }^{80}$

40 French industrialisation was undertaken with a different aim and focus than was British industrialisation. During the reign of Louis XVI, ${ }^{81}$ industrial production had been increased by the hand machines introduced from England and steam engines were coming to be used in the mines. ${ }^{82}$ However, the French reliance on foreign technology carried with it its own problems. It required that the foreign technology be aligned with local craft practices and expectations and the skills needed to operate foreign machines and systems were not always immediately present. French workshops and artisans of the eighteenth century evolved into small businesses and the petite bourgeoisie. France maintained a small scale industrial character during a period when rapid industrialisation was occurring throughout Western Europe. Instead of the decomposition of traditional trades, France remained a small scale producer until the twentieth century. Luxury and fashion trades remained the most common, which allowed for and indeed encouraged the continuance of small scale artisanal production. French exports were dominated by artefacts associated with the traditional luxury trades even until the last quarter of the nineteenth century. ${ }^{83}$ While today French industry is competitive in the global economy, it is still known for its artisan and luxury trades produced by relatively traditional means.

41 While the British quest for profit was king, there was less of a focus on moneymaking in France than on how France would be able to adopt the industrial economy to the nature and culture of the French nation. While France lagged behind England in industrialisation generally, there were steady improvements during England's period of rapid growth. Technical progress was also delayed by the turbulent and revolutionary nineteenth century as well as the Napoleonic wars. ${ }^{84}$ Little changed during the twenty five years of revolutions, empires and restorations, but by the mid-nineteenth century, large scale industry had undergone a transformation on the English model. Machines fired by coal were being used, which changed the conditions of work for industrial labourers. ${ }^{85}$

42 Wealth in France remained in real property throughout the nineteenth century. Merchants and industrialists were not rich as they were becoming in England. There were also hardly any rich employers of labour except in the textile and

\footnotetext{
${ }^{80}$ Ibid., at 12 .

${ }^{81}$ Reigned 1643-1715.

${ }^{82}$ Seignobos, above note 65 , at 279 .

${ }^{83}$ M. Sonescher, Work and Wages: Natural law, politics and the Eighteenth Century Trades (1989, Cambridge University Press, Cambridge), at 370-375.

${ }^{84}$ C. Heywood, The Development of the French Economy 1750-1914 (1992, Cambridge University Press, Cambridge), at 31-32.

${ }^{85}$ Seignobos, above note 65 , at 337.
} 
mining industries. Large scale industry was not yet common and was only introduced as a result of the introduction of English textile manufacturing machinery as well as certain new chemical processes. While the power rested primarily in the bourgeoisie, they generally dreaded commercial and industrial enterprises in which money could be exposed to risk. ${ }^{86}$ The memory of the bursting of the Mississippi Bubble was still clearly present and influencing French investment choices.

43 Thus, France took a steady approach toward industrialisation. There was first a massive expansion of industry in the countryside relying on small scale cottage production that laid the groundwork for large scale industrialisation. Peasants in the countryside relied upon their cottage industries during the slow agricultural seasons, which helped to compensate them for excessive divisions of landholdings or the precarious existence of tenant farmers and agricultural labourer. Merchant manufacturers were content to exploit this ready supply of labour. This form of industrial organisation was a resilient French system. However, this type of protoindustrial economy would not be able to keep up with competitors so would have to transition to a more scientifically and technologically dynamic economy in the nineteenth century. ${ }^{87}$

44 The quality of French industrialisation was also characterised by a form of flexible specialisation aimed to develop increasingly sophisticated versions of artisan tools for the use of skilled labour. The new machinery still made heavy demands on the skills of the operative, unlike specialisation in British industry that mainly required repetitive small tasks of its unskilled labour force. The skill focussed specialisation was, however, well suited to the craft traditions of French labour by catering to creativity and quality. The flexible specialisation could not, however, replace the profit making ability of mass production, despite the fact that it likely produced higher quality and more diverse goods. ${ }^{88}$ France was slow to concentrate production but an increasing sub division of tasks eventually led to a de-skilling of the labour force. This de-skilling of certain sectors of the labour force reduced individual wages such that in comparison to those who continued to work in at least semi-skilled industries, income distribution was increasingly unequal. Such inequality of income distribution then acted as a drag on industrial consumption, decreasing economic growth. ${ }^{89}$

45 Britain's early industrialisation allowed the modern business enterprise to emerge before its legal system could move beyond late medieval and early modern forms of legal regulation. In France, private law codes had been introduced decades before large scale industrialisation occurred. These differences had profound

\footnotetext{
${ }^{86}$ Ibid., at 319-321.

${ }^{87}$ Heywood, above note 84 , at $32-33$.

${ }^{88}$ Ibid., at 33-34.

${ }^{89}$ Ibid., at 34.
} 
implications for both legal and economic development. In Britain, institutions had to hurry to catch up with the pace of industrialisation and evolved in order to suit its requirements while in France institutions such as the employment contract and companies limited by share capital were already in place and able to support the emergence of large scale business enterprises. ${ }^{90}$

\section{Proletarianisation}

\section{In the UK...}

46 Proletarianisation was the process whereby dependence upon the dictates of capitalist relations increased among the labouring classes. It was not solely the subordination of the labouring classes to a technically driven labour process, but a process occurring in the sphere of market relations that involved an increased exposure to the vagaries of market forces. Employees were less able to bargain with their employers and were more dependent than before on a single source of income, thus had to work on any terms they could achieve. ${ }^{91}$ Even before large scale industrialisation occurred, the English peasants were already dependent upon selling their labour power, thus the proletarianisation of the English had begun in advance of the Industrial Revolution. ${ }^{92}$ Two thirds of the rural and urban labour force was wage earning and rent paying as early as the late sixteenth and early seventeenth century. ${ }^{93}$ Small craftsmen still in the workshop industry steadily became more dependent upon the industrialist machinery of the large factories. As small craftsmen were unable to compete effectively with the larger manufactories they were reduced to performing certain limited stages of production as subcontractors to the large producers. The small producers' reliance on the credit granted by the larger manufactories increased their dependence. Competition between small workshops also led to lowering working standards and wages as well as the adoption of tightened discipline among employees. ${ }^{94}$

47 The saturation of the labour market by unskilled workers as well as the introduction of machinery led to a process of deskilling of the labour supply. Specialisation and division of labour had further simplified industrial processes, making it easier for workers to move from one occupation to another. ${ }^{95}$ Specialisation was fed by these unskilled workers and contributed to the dissolution of traditional household economy as women and children entered into direct competition with men. Wages reduced as competition rose in the labour market. ${ }^{96}$

\footnotetext{
${ }^{90}$ Deakin, Lele and Siems, above note 15 , at 140.

${ }^{91}$ R. Price, Labour in British Society (1986, Routledge, London), at 21.

92 Deakin and Wilkinson, above note 70 , at 44.

${ }^{93}$ L. Clarkson, "Wage Labour 1500-1800", in K. Brown (ed.) The English Labour Movement 17001951 (1982, Gill and Macmillan), at 1-27; Deakin and Wilkinson, above note 70, at 44-45.

${ }^{94}$ Price, above note 91 , at 22-23.

${ }_{95}$ Ashton, above note 75 , at 1-2, 41 .

${ }^{96}$ Price, above note 91 , at 25 .
} 
Peasant men and women came to live crowded together earning their living as units of the labour force in factories rather than as communal groups of families and neighbours working together to produce from the land. Labour had become more mobile and flexible and opportunities were now made available, promising higher standards of comfort to those able to relocate. ${ }^{97}$ There was no strong desire among those who would become factory hands to congregate in large industrial centres. Rather, they were under the spell of powerful economic forces that transformed them into a working class. ${ }^{98}$

48 Initially, it was rare for workers to seek continuity of work as casual hiring methods engendered casual working habits. Essentially, workers sought work when funds were needed to satisfy the needs of the worker and his family. The preference of leisure time and the fact that most workers were paid by the piece led to the rapid and sometimes negligent or substandard production of goods in order to gain the cash in as little time spent working as possible. This led to requirements of working hours and eventually to the widespread use of employment contracts which would stipulate standards, hours and wages. Eventually, workers became inured to the regularity of work, although the process of conditioning the labour force to stricture rules of working was difficult and unpleasant. However, had code of conducts and working rules not been imposed during the early days of the Industrial Revolution, there could have been no factory system or rise in output that led to an improvement in working conditions during the nineteenth century. ${ }^{99}$

49 Proletarianisation was a complex process of interaction between a growing subdivision of labour stimulated by market demand, the expansion of the labour market and the appearance of boom and slump trading cycles. Trading cycles encouraged the movement between trades and the abandonment of customary protections such as apprenticeships. Slumps in the market allowed standards and wages to reduce while workers and small contractors suffered increased dependence upon single large masters. ${ }^{100}$ What is peculiar to the UK is that while there were no formal classes, traditional reciprocities, obligations, cultural and social relationships nonetheless coexisted with economic forms of capitalism. ${ }^{101}$

\section{In France...}

50 Women and child labourers were used in the end of the eighteenth century for mechanical unskilled work in both manufactories and mechanised industry. In France, manufacturing had been changed in that it was now done on a large scale under the supervision of foremen. Workers were regarded merely as instruments for

\footnotetext{
${ }^{97}$ Ashton, above note 75, at 1-2, 41 .

${ }^{98}$ Ibid., at 88 .

${ }^{99}$ Ashton, above note 74, at 203.

${ }^{100}$ Price, above note 91 , at 25 .

${ }^{101}$ Ibid., at 21.
} 
performing work and industrialists kept a distant relationship with them. Their conditions of life, food, housing and health were of no concern. Wages were reduced to the lowest possible level in order to decrease the cost of production. Workers were recruited among the most destitute class of people in the poorest regions where an increase of population had produced a surplus having no means of subsistence in order to take advantage of their desperation. There was no security in employment and not enough money was made to save for the future of working families. Life was miserable, crowded, dirty and unhealthy. Work was monotonous, often dangerous, and the work day was unlimited. ${ }^{102}$

51 Where once a person's occupation was a part of their social standing and indeed their family and personal identity, such large scale industrial work had reduced the humans providing labour to commoditized elements of production. Workers forged no links with their workplace. There were no common traditions or organisations for mutual aid. Associations were still forbidden so the only means to improve their situation was illegal. They were completely dependent upon their employer who fixed their wages and working hours arbitrarily. Employers had no responsibility toward their employees if they fell ill or were injured as a result of the work they did for him. ${ }^{103}$ However, the heavy industrial sector of France did not replace the traditional, but rather developed alongside it.

52 The industrial proletariat in France evolved slowly. Industry was initially divided into a small modern sector and a traditional one based on home craft activities. Industry was thus populated by a mass of small peasant owners and a large number of independent handicraftsmen spread out among the rural areas and within the budding industrial centres. There was no massive transfer from rural to urban centres that characterised industrialisation in the UK. There was instead a slow development of a diversified proletariat by successive strata of a nonhomogenous population from different socio-economic backgrounds constituted by successive waves of farm hands, part time peasants, migrant workers, women leaving home for work, craftsmen and former self-employed handicraftsmen. The proletariat was therefore composed of a diverse working class. ${ }^{104}$

\section{The Employment Relationship}

53 The British employment relationship was based on a master and servant model connected to the early legal form of social relations that was a statutory and hierarchical paradigm rather than based in contract and common law. This hierarchical form can be traced from the pseudo-feudal roots of the British classist society and the inherent conservatism of the populace, who later became the

\footnotetext{
102 Seignobos, above note 65 , at $337-338$.

103 Ibid., at 338 .

${ }^{104}$ M. Despax, J. Rojot and J-P. Laborde, Labour Law in France (2011, Kluwer Law International, Alphen aan den Rijn), at 210.
} 
industrial working classes. The master and servant form of employment relationship relied upon a command relation with an open ended duty of obedience imposed on the worker, reserving far reaching disciplinary powers to the employer. ${ }^{105}$ Even once the employment relationship had been given the status of contractual relationship imposing certain civil obligations, the hierarchical characteristic of the traditional master and servant model were carried over into the contractual employment relationship. ${ }^{106}$ Legal terminology and the old assumptions of unmediated control continued to be applied by the courts as they developed the common law of employment. The advent of the welfare state and the extension of collective bargaining caused employment law to change direction, but the traditional hierarchy of employer and employee remained difficult to dislodge from the legal psyche. ${ }^{107}$ While this has been tempered since the 1940s and given legal status following the introduction of the Employment Rights Act of 1996 as well as other more progressive employment oriented legislation, the master and servant approach is still evident in Britain's regulatory approach to employment law. ${ }^{108}$

54 The French employment relationship began with a similar approach to that of the UK. Labour contracts were initially grouped among other types of contracts, thus also based on exchanges within the market, effectively commoditising labour by linking it with price through the institution of contract. In the early legal codes, the concept of the subordination of the worker was absent, though this concept would come to define the French employment relationship. The practical reality was that an employer had the power to give orders, issue binding rules, and even retain the worker in employment until the employer considered that the work was complete. The contrat du travail ${ }^{109}$ entered into general usage in the 1880 s due to an argument by larger enterprises that a general duty of obedience should be read into all industrial recruitment. Eventually, the contrat du travail would be promoted and systematised by those charged with developing the conceptual framework for collective bargaining and worker protection. The contrat du travail would become the core of the French employment relationship, the central pillar of which was the principal of subordination in which the employee's duty of obedience was exchanged for the acceptance and absorption by the enterprise of a range of social risks. ${ }^{110}$

55 The master and servant relationship prevailed in Britain until quite recently and its echoes can still be observed in the nature of British labour and employment regulation. Its continued existence was due in part to the parallel existence of

\footnotetext{
105 S. Deakin and W. Njoya, "The Legal Framework of Employment Relations", (2007) Centre for Business Research Working Paper Number 349, at 7.

${ }^{106}$ Lord Wedderburn of Charlton, "The Social Charter in Britain" (54)1 The Modern Law Review 1-47, at 6.

${ }^{107}$ Deakin and Njoya, above note 105 , at 7.

${ }^{108}$ Lord Wedderburn of Charlton, above note 106, at 6 .

109 Translated as contract of employment.

${ }^{110}$ Deakin and Njoya, above note 105 , at 9 .
} 
capitalist enterprise and the fading pseudo-feudal tradition. Eighteenth century social relations continued to be characterised by reciprocities, obligations, cultural and social relationships that were customary and traditional in character. At the same time, the objective conditions of production had created a class of industrial workers who remained emotionally and mentally tied to the traditions of class, if not the class structure and its distinctions. As demand for industrial products grew, restraints on the market left over from the days of mercantilist economics fell away. The working classes were increasingly dependent upon the dictates of capitalist relations and were steadily subordinated to it. By the end of the eighteenth century, workers had less power to bargain with their employers than they had in 1700 . They were dependent on a single source of income and therefore were forced to work on whatever terms they could get. ${ }^{111}$

56 The late appearance of a more equitable concept of the employment relationship in the UK had the effect of institutionalising the conception of the enterprise as the employer's unencumbered property. The new economic relationship of employer and employee was based upon a concept of private property (capital) provided by the employer for the employee to be used in order to perform the services for which he is being paid. The employee became wholly dependent upon the industrial employer, in some cases for food, shelter and the education of his children as well as for the tools and place of his trade. ${ }^{112}$ Continental concepts of work relations imposed a juridical equality between worker and employer which was embodied in the legal codes. In France, the employer's control over employees was tempered by the development of mandatory social legislation. ${ }^{113}$

\section{Collectivism and the Labour Movements}

57 Although initially association for the purposes of exerting pressure on employers to improve the position of employees was forbidden, a leftover from the first, though negative, labour regulation in both England and France issued during the rise in the demand power of labour during the time of the Black Death, it was eventually freed in both countries. Labour movements had been viewed as an interference with the free market economy and though their prohibition was actually interference, it left labour to be regulated by market forces operating through voluntary contracts. Guild regulations and other obstacles were also swept aside. The work book system was introduced on the continent while Britain pursued penal sanctions against deserting workers. These persisted until the last quarter of the nineteenth century. ${ }^{114}$

\footnotetext{
${ }^{111}$ Price, above note 91 , at $15-28$.

${ }^{112}$ Hepple and O'Higgins, above note 63, at 12-13.

${ }^{113}$ Deakin, Lele and Siems, above note 15, at 140.

${ }^{114}$ Hepple and O'Higgins, above note 63, at 18-19.
} 
58 Once suffrage was extended in $1867,{ }^{115}$ the unyielding power of British industrialists began to be tempered by the will of the voting working classes. In the 1870 s the penal sanctions for quitting and prohibitions on the right to association were removed. Due to the fragmented proletariat in France, however, it wasn't until the 1890s that similar freedoms were instituted. While in Britain, the new found freedom saw the evolution of unions and the power of collective bargaining, which eventually grew to obtain significant political power in the Labour Party, in France political influence, particularly by the Socialist party, was exercised as a means of achieving guarantees for more favourable working conditions. Collectivism itself was instituted in a top down fashion, while in the UK bargaining began at enterprise level. ${ }^{116}$

\section{Labour in Britain}

59 In Britain, a principle of collective laissez faire was espoused that allowed employee organisations to bargain freely within the labour market with minimal government or regulatory interference. Thus, any mechanisms or procedures created before the middle of the twentieth century were implemented through trade unions and the institutions of collective bargaining. For employees in Britain this meant that the participants in industrial relations played a much more important role in the regulation of their own activities than they would have done in a more interventionist regime. ${ }^{117}$ For example, in the early twentieth century Britain viewed the duty to regulate or otherwise control working hours as belonging solely to the remit of collective bargaining and was therefore unwilling to ratify the International Labour Organisations Convention on the forty eight hour work week. ${ }^{118}$ Direct regulation of the employment relationship was not a matter for law, but for the social institutions of industrial relations. ${ }^{119}$

60 The collective laissez faire preferred in Britain limited the intervention of the law to those marginal areas where there was a disparity between the forces of organised labour and organised management that impeded the successful operation of the negotiating machinery. ${ }^{120}$ Even where such disparity existed, labour regulation was light. The collective bargaining system evolved independently of the law and little was done to regulate or even recognise the legal standing of trade unions and their bargains. However, despite the free reign of unionist bargaining in the UK, individual rights were not necessarily protected. Individuals could be

\footnotetext{
115 See the Representation of the People Act 1867 (30 \& 31 Vict. c. 102) (known as the Reform Act of 1867).

${ }^{116}$ Hepple and O'Higgins, above note 63, at 22-23.

${ }_{117}$ P. Davies and M. Freedland, Labour Legislation and Public Policy (1996, Oxford University Press, Oxford), at 8-10.

${ }^{118}$ Lord Wedderburn of Charlton, above note 106, at 4-5.

${ }^{119}$ Davies and Freedland, above note 117, at 8-10.

${ }^{120}$ O. Kahn-Freund, "Labour law" in Selected Writings of O Kahn-Freund (1978, Stevens Publishing), at 8 .
} 
discriminated against by trade unions on the basis that they were not a member. Further, the purpose of the collective agreement often lay within the control of the employers and unions thus did not confer an entitlement to protection upon individual employees. ${ }^{121}$ Individual protection did not arise until the 1960 s when statutory regulation was passed to protect employees from unfair dismissal. ${ }^{122}$ This was the first step made by the UK away from the policy of collective laissez faire toward direct statutory regulation of the employment relationship, which was soon accompanied by a steady erosion of the free reign of labour interests that had become a serious impediment to the British free market economy.

61 The growth of the union culture and collective bargaining in Britain in the early twentieth century was characterised by a lack of demand for changes to the law. Rather than using the law as a means of securing better conditions, higher wages and other employment benefits, British unions had discovered a better, more flexible means of looking after their members. ${ }^{123}$ The apolitical nature of unions during the early days of collectivism in Britain is one of the major differences between the development of unionism in the UK as opposed to in France. French unionism developed simultaneously with a mass political labour movement and its political parties. In Britain, the trade union organisation came first and the political movement later. The lack of political association of the early British labour movements led to agitation for a protected space within which trade unions could collectively bargain and negotiate without the interference of politics or even the law, which justified the principal of collective laissez faire as a basis for British labour interests. ${ }^{124}$

62 While the function of trade union rights in the UK is similar to those of other continental democracies; the form that they take has traditionally been radically different. Rather than protecting the freedom of association through the granting of positive rights, the UK has generally granted immunities for certain trade union activities that could otherwise constitute civil law liabilities, ${ }^{125}$ such as conspiracy. Although strike action is "immune" from prosecution, striking employees will usually be taking action in breach of their employment contract, for which they could be sued by their employers. ${ }^{126}$ While such action by employers is rare, the fact that it is possible again emphasises the importance British courts and law makers place on the sanctity of freedom to contract.

63 The resistance to regulation in the area of labour law in the UK is influenced by the nature of the labour movement in Britain. Given the development of trade

\footnotetext{
${ }^{121}$ P. Davies and M. Freedland, above note 117, at 52-53.

${ }^{122}$ First provided for in the Contracts of Employment Act 1963.

123 W. McCarthy (ed), Legal Intervention in Industrial Relations: Gains and Losses (1992, Basil Blackwell Limited, Oxford), at 4-5.

${ }^{124}$ Lord Wedderburn of Charlton, above note 106, at 7.

125 Ibid., at 3 .

${ }^{126}$ Ibid., at 8.
} 
unions outside the political sphere and the far reaching freedom to act that they were given through immunities, it is not surprising that they were not supportive of the encroachment of the law into industrial policy. Britain's adherence to orthodox economic beliefs in the free market, collective laissez faire and the lack of political ambitions to affect legislative policy in early unionist dogma meant that there was little support for any progressive labour regulation. ${ }^{127}$ This non-interventionist stance has remained popular in British politics, though successive Labour governments have tempered this with more progressive legislation, particularly in view of Britain's acceptance of the EU Social Chapter.

\section{$\underline{\text { Labour in France }}$}

64 Collective bargaining was also an important mechanism through which employment relations were managed in France, however, the legal systems recognised trade unions and also legally instituted enterprise level works councils. These generally involved the compulsory establishment of works councils and the election of representatives, placing a legal obligation upon the employer to give information to works councils and consult with it over matters of concern to employees. Continental works councils have the legal standing to compel the employer to treat his employees on a collective basis. While in Britain, the organisation of the workplace is based on the voluntary organisation of trade unions and their negotiations with employers, continental workplaces tended to be organised according to legal principles. ${ }^{128}$

65 In France, the development of large scale industry and mechanisation in the framework of the capitalist system brought formerly isolated workshop labourers physically together within factories. Although a legal prohibition on collective organisation persisted into the middle of the nineteenth century, this new community of working class people allowed a collective consciousness of solidarity to emerge that led to worker organisation through which they could act to obtain guarantees previously lacking. It was in the 1840s that the misery and debilitating working conditions of the working classes was finally recognised in France. As industrialisation increased its pace along with the misery of the workers, liberal capitalism was blamed by a number of socially progressive groups as well as by the workers themselves. ${ }^{129}$

66 While the Second Republic ${ }^{130}$ acknowledged the right to work, limited the working day to ten hours and created the forerunner to a ministry of labour, it remained suspicious of labour organisation. However, in 1864 the felony of

\footnotetext{
${ }^{127}$ R. Lowe, "Hours of Labour: Negotiating Industrial Legislation in Britain, 1919-39" (1982) 35(2) The Economic History Review 254-271, at 270.

${ }^{128}$ Davies and Freedland, above note 117 , at $16-17$

${ }^{129}$ Despax, Rojot and Laborde, above note 104, at 49-50, 194-195.

${ }^{130}$ 1848-1852.
} 
conspiracy which had often been used against collections of striking workers was eliminated, opening the way towards lawful strikes. The law of 1884 then repealed the existing texts contrary to trade union freedom, insured their independence from the state, and granted freedom to organise as well as to not belong to a union. The right to strike was later positively protected in the Constitution of the Fifth Republic in 1946. It was also under this Constitution that works councils were introduced into the structure of private enterprises and a place was given to the representatives of employees. ${ }^{131}$

67 The evolution stemming from the so-called "long nineteenth century" beginning with the French Revolution and ending with the commencement of World War I ${ }^{132}$ left a deep mark which is still visible in the present labour regime. Early in the labour movement, there was no strict division of labour organisations between political and union activity. Social reformers, economists and political ideologues were all involved in the labour movement, rendering it fundamentally political in form. ${ }^{133}$ The labour movement took on a pluralistic character rather than as a unified labour movement that characterised the British process. Trade unions in France were divided along ideological lines. Thus, workers at a particular establishment could be members of different unions based on their political or philosophical affinity, such as Communist, Progressive, Socialist, or Christian or some other political or dogmatic confederation. However, trade union membership now attracts only a relatively small percentage of the workforce. This is in part due to the existence of enterprise level representation in work councils and employee representatives. ${ }^{134}$ The individualistic nature of France is also contrary to the inherent collectiveness in unionism, which may also contribute to the low membership. This does not stop the persistence of wildcat strike action and other forms of collective resistance or activism that is guaranteed under the human rights protections enshrined in the French Constitution and sacredly respected by the people.

68 Labour policy has since become a tool of political power in the UK and France. The course of British Labour policy has been circuitous with far more violent swings in policy than was experienced in France. This can be explained in part through the more general social causes affecting each jurisdiction but also by reference to the legal culture itself. The British common law system is infinitely malleable in comparison to the French codified system ${ }^{135}$ and can thus be easily affected by political shifts. British Conservatism in the 1980s emphasised the need to free labour markets in order to compete in the global economy, which led to a substantial weakening of the power of labour interests in favour of its replacement

\footnotetext{
${ }^{131}$ Ibid., at 49-50, 194-195.

13228 July 1914-11 November 1918.

${ }^{133}$ Despax, Rojot and Laborde, above note 104, at 209.

${ }^{134}$ M. Forde, "Trade Union Pluralism and Labour Law in France" (1984) 33(1) The International Comparative Law Quarterly 135-157 at 134-136.

${ }^{135}$ Lord Wedderburn of Charlton, above note 106, at 12.
} 
by regulation. As governments have changed between political parties so has the strength of labour regulation, making the area of employment law one of the least reliable and most changeable in the UK legal system. Similarly in France, as socialism gained ground in the 1980s, so too did labour reforms become increasingly protective, though not with the same alacrity as in Britain. In both jurisdictions, political changes are typically accompanied by changes to the protectiveness of labour law. ${ }^{136}$

\section{Labour Regulation}

69 Modern labour law is a product of industrialisation developed in view of certain social and economic factors that were prevalent early in the Industrial Revolution. It was developed for workplaces embedded in factories where employees worked in a collective manner. Continuity and stability were important factors in employment and businesses were characterised by clear hierarchical structures. There was a clear division between the employer's power to command and control and the employee's subordination to that power, a dichotomy that continues to define the scope of labour law today. However, in the post-industrial era that can describe the economies of most Western European countries, most of the elements of early industrial society no longer exist. Employees work in increasing isolation and the enterprise itself is no longer defined by location and building. ${ }^{137}$

70 In Britain, labour regulation emerged long after the beginning of the Industrial Revolution. It could be surmised that the implementation of labour law does not occur only as a result of the factors of production existing at the time, but actually reflects the economic and social structures of a jurisdiction. ${ }^{138}$ The modern cultural and social values in France have led to a liberal and social conception of labour law, giving a great role to the freedom of association and union activities, encouraging social dialogue and fighting against every form of discrimination. It also ensures widely guaranteed incomes either at work or in the case of unemployment. ${ }^{139}$ British labour regulation, however, was instituted only after the power of labour interests had grown to the point that they were able to wield real and damaging political power. Thus labour regulation was introduced first with broadly economic impulses aimed at replacing the power of labour interests in order to take control of the labour economy and later in order to meet minimum limits set by EU law.

71 In the French system, the power of the state to regulate conditions of work was instituted within the legal system through the concept of ordre public social, ${ }^{140}$ a set

\footnotetext{
${ }^{136}$ Deakin, Lele and Siems, above note 15, at 145-146.

${ }^{137}$ M. Wesis, "Re-inventing Labour Law?", in Davidov and Languille (eds.), above note 46, at 43-56.

${ }^{138}$ Hepple and O'Higgins, above note 63, at 14-15.

${ }^{139}$ Despax, Rojot and Laborde, above note 104, at 33.

${ }^{140}$ Essentially this is the French version of social policy (translated directly as "social order"), which is aimed at guaranteeing the fundamental rights of French citizens.
} 
of minimum binding conditions applied as a matter of general law to the employment relationship. This concept recognised that as there should be a formal contractual equality between the parties of an employment relationship. Ensuring that this equality existed in practice meant that the state had to assume a responsibility for establishing a form of protection for individual workers who, by accepting employment, were placed in a position of subordination to employers. ${ }^{141}$ Thus, the state assumed a role of calibration for the natural imbalance in power between employer and employee. Labour law differs from French civil law in that it takes the inequality of the contracting parties as the point of departure, while civil law assumes bargaining equality. Labour law also integrates a dimension for collective relations while civil law governs individual relationships based on the assumption that where an individual employee cannot bargain on an equal footing with an employer, then trade unions or other collective organisations can do so. The French labour law is therefore a special law operating alongside civil law that is then referred to in those instances where labour law does not cover certain circumstances. ${ }^{142}$

72 Since the end of the 19th century, the degree of government intervention has been very important owing to the strength of its ideological and philosophical bases. Rather than the value that the British system places on freedom from government intervention, regulation was viewed as a means of liberating the oppressed, particularly those of the working classes. Further, France did not distrust the state or government intervention, unlike its neighbour across the channel who preferred to retain their regulation-free area within the sphere of trade unionism. ${ }^{143}$ Rather, France has chosen the route of direct government regulation of the terms and conditions of employment for all employees, whether unionised or not. French labour organisations are also more politically oriented, having become accustomed to accomplishing their aims through political action rather than negotiation. Collective agreements themselves have occasionally become the subject of statute, eventually binding even those companies who did not agree to their terms. ${ }^{144}$

73 France also introduced works councils following the end of World War II with the aim of associating the workers more closely with the functioning of the enterprise. Employers owe a number of duties to works councils to inform and consult with them on matters concerning the organisation, management and general running of the firm and in particular on any measures likely to affect the volume or structure of the work force, duration of work, employment, work and vocational training conditions. ${ }^{145}$ There is no similar organisation in the UK system. Though information and consultation exercises are required from time to time, these will

\footnotetext{
${ }^{141}$ Deakin and Njoya, above note 105 , at 9 .

${ }^{142}$ Despax, Rojot and Laborde, above note 104, at 36-37.

${ }^{143}$ Ibid., at 56.

${ }^{144}$ M. Glendon, "French Labor Law Reform 1982-1983: The Struggle for Collective Bargaining" (1984) 32(3) The American Journal of Comparative Law 449-491, at 470-471.

${ }^{145}$ Despax, Rojot and Laborde, above note 104, at 255-258.
} 
generally be with a representative group of employees especially comprised in order to meet the requirements of the exercise. In France, these work councils are a fundamental part of the labour law system.

74 In the UK, an emphasis has remained on the importance of some form of economic liberalism and the free market, while France has steadily drawn away from these ideas toward the social democracy which is characteristic today. France has manifested a certain reserve about the market economy and capitalism through its political and economic policies. ${ }^{146}$ Clearly, the French system has taken a view on the importance of social protections and this view is imposed upon any legislative act which may affect society.

\section{Conclusion}

75 Though both jurisdictions began with an economically liberal view on factors within the economy early in their times of industrialisation, the effect of France's view on the rights of the worker and the importance of protecting individual dignity led to social policies becoming a fundamental tenet of their legal system. The acceptance of redistribution as a means of attaining justice and equality and the French resistance to capitalist economics makes regulation of social policy a moral requirement rather than a perceived economic hindrance. Social policy matters were subsumed within the foundations of the legal code, becoming a factor endogenous to the system which will always have an effect on the aims of regulation. Social policy in the UK came about as an afterthought drawn out by socially minded politicians and judges and eventually imposed through the exercise of EU legislative supremacy. While today social policy goals are a normal part of the UK political scene, the question in France is more about how far it can go without being a detriment to itself.

76 The differing approaches to social policy are fed by factors relating to history, economy, society, culture and the idiosyncratic paths upon which labour systems evolved in the different jurisdictions. The manner of industrialisation is evidence of two very different approaches as well as different values placed upon tradition and culture over profitable gains. As Britain worshipped at the altar of mammon, feeding its industrial machine with the poor and dispossessed, France took a steady approach with greater care and consideration for the traditional industries already in place. The industrial proletariat was also differently composed, due in part to the enclosure of the English countryside which forced English peasants into industrial centres, an experience that did not occur in France. As such, the French proletariat was diverse leading to diverse approaches to the problems occasioned during industrialisation.

\footnotetext{
${ }^{146}$ Ibid., at 33-34.
} 
77 The character of the employment relationship is also demonstrative of the historical factors affecting the evolution of social policy. French feudalism, the absolute monarchy and then the catastrophic fall of the ancien régime have affected the way in which the employment relationship is viewed in France, taking from the pre-revolutionary context the subordinate nature of employees and the obligations of employers and the compassion and recognition of the need to balance this relationship from the ideals of the revolution itself. Britain, however, retains its master and servant style of contractual approach, placing the duty on both to comply with the contractual terms governing the relationship, but allowing each freedom to negotiate and to breach agreements without the intervention of regulatory provisions.

78 The character of collectivism in the UK and France are fundamentally different. While France places an ultimate value on the freedom to associate and positively protects those rights, the UK has kept as much distance as possible while considering the effects of the power of collective labour interests on the economy in negative immunities. Though the balance of labour interests to labour regulation has changed today, the attitude of laissez faire is still present in the system. Further, France has legally integrated collective rights through the presence of works councils and employee representatives, a quality that arises in the UK only when certain events trigger the requirement for information and consultation. In addition, the nature of the working classes differs due to the historical experiences of each. The French proletariat tends to exhibit an individualism that can be traced back to the ideologies of the French Revolution which is evident in the pluralist nature of French trade unionism. The communitarian nature of the English working classes is, however, constitutive of a village community culture which was retained to some extent by the homogenous proletariat of the Industrial Revolution, making collective action more natural.

79 Individualism and freedom are cornerstones of French society that arise throughout the history described herein. The importance of human dignity, pluralistic labour interests, the representative character of French business structures, and the heterogeneous nature of the proletariat that evolved during industrialisation are only an example of the elements of society and culture that have continually affected French legal culture. The UK is nearly opposite in all of these areas. While indeed freedom is valued, it is valued beyond the individual "rights" to comfort and dignity. Individuals are expected to look after themselves rather than relying on the state to ensure that businesses do not perpetrate abusive policies on workers. With these extraordinarily different characteristics in mind, it is not surprising that the centre of the French insolvency and corporate rescue regimes sits the protection of employment rather than of creditors, who are generally business entities. While France respects the separate personality of businesses, it is clear that they do not occupy the same space in terms of rights that individual humans do. 
80 With differences so fundamental as these, it must be queried how it might be possible to overcome these obstacles in order to draw their legal systems into closer alignment, at least in relation to cross-border insolvency and the effect of employment protection on its efficiency. In order to find a common ground between the UK and France, it would be necessary to speak to the UK desire to promote business and the free market while considering the French requirement to protect individual employee interests with an understanding of the path dependent context influencing these positions. This would require a complete rethinking of the approach to coordination in legal reform, but one that might achieve more a more effective result. 